\title{
AGRICULTURE, HABITAT LOSS AND SPATIAL PATTERNS OF HUMAN OCCUPATION IN A BIODIVERSITY HOTSPOT
}

\author{
José Alexandre Felizola Diniz-Filho ${ }^{1 *}$; Guilherme de Oliveira²; Fábio Lobo ${ }^{3}$; Laerte Guimarães \\ Ferreira $^{4}$; Luis Mauricio Bini ${ }^{1}$; Thiago Fernando Lopes Valle Brito Rangel ${ }^{5}$ \\ ${ }^{1}$ UFG/ICB - Depto. de Ecologia, C.P. 131 - 74001-970 - Goiânia, GO - Brasil. \\ ${ }_{3}^{2} U F G / I C B$ - Programa de Pós-Graduação em Ecologia e Evolução. \\ ${ }^{3} U F G$ - Programa de Pós-Graduação em Ciências Ambientais (CIAMB). \\ ${ }^{4} U F G$ - Instituto de Estudos Sócio Ambientais. \\ ${ }^{5}$ University of Connecticut-Department of Ecology and Evolutionary Biology, 75 North Eagleville Rd., Unit 3043, \\ Storrs, CT, 06269-3043 - USA. \\ *Corresponding author <diniz@icb.ufg.br>
}

\begin{abstract}
The Cerrado biome, the second largest biome in Neotropical region, consists of a mosaic of different habitat types, ranging from open grasslands to dense woodlands and dry forests. An intensive recent occupation process has transformed it into the most important region for cattle ranching and intensive commodity crops in Brazil. In this study, a macroecological approach was used to evaluate broad-scale spatial patterns of habitat loss in the Brazilian Cerrado, applying a series of spatial autocorrelation and partial regression analyses to understand how the proportion of remaining natural habitats is correlated with socio-economic variables, expressing different dimensions of human occupation and climatic variation. On average, $59 \%$ of the area is occupied by natural remnants at the spatial scale analyzed, although patterns of habitat loss are strongly spatially structured, with a Moran's $I$ spatial autocorrelation coefficient equal to $0.825 \pm 0.055(p<0.001)$. The partial regression analysis explains $89 \%$ of variation in percentage of natural remnants. The highest proportion of variance is explained by the multiple overlap between human occupation, climatic variation and geographic structure $(67 \%)$, as well as by the climatically structured component of human occupation $(8 \%)$. Based on the space-time interactive process of human occupation in the biome, future scenarios should be rather pessimistic. If the wave of human occupation continues towards the northern parts of the biome, as expected, we can predict that percentages will decline rapidly including even stronger losses of habitat at the biome scale.
\end{abstract}

Key words: MODIS, Brazilian Cerrado, spatial autocorrelation

\section{AGRICULTURA, PERDADE HÁBITAT E PADRÕES ESPACIAIS DE OCUPAÇÃO HUMANA EM UM “HOTSPOT” DE BIODIVERSIDADE}

RESUMO: O bioma Cerrado é o segundo maior da região Neotropical e é formado por mosaico de diferentes tipos de hábitats, desde campos abertos até florestas densas. Um recente e intensivo processo de ocupação humana tem transformado essa eco-região em uma das mais importantes regiões para agropecuária no Brasil. Uma abordagem macroecológica foi utilizada para elucidar padrões em amplas escalas espaciais de perdas de hábitat no Cerrado brasileiro, implementando técnicas de autocorrelação espacial e análises de regressão parcial para entender como a proporção de remanescentes de vegetação natural está correlacionada com variáveis socioeconômicas, expressando diferentes dimensões de ocupação humana e com variações climáticas. Em média, 59\% da área é ocupada por remanescentes de vegetação, na escala da análise, mesmo que os padrões de perda de hábitat estejam fortemente estruturados no espaço, com o coeficiente de autocorrelação espacial de $I$ de Moran igual a $0,825 \pm 0,055(p<0,001)$. As análises de regressão parcial explicaram $89 \%$ da variação no percentual de remanescente de vegetação. A maior proporção da variância é explicada pela sobreposição múltipla entre a ocupação humana, variação climática e a estrutura geográfica (67\%), bem como pelo componente estruturado climaticamente da ocupação humana ( $8 \%)$. Baseado no processo interativo no tempo e no espaço da ocupação humana no bioma, cenários futuros devem ser mais pessimistas. Se o movimento de ocupação continuar em direção a região Norte do bioma, como esperado, nós podemos predizer que as proporções de remanescente de vegetação natural irão declinar rapidamente, indicando assim uma forte perda da biodiversidade nas escalas do bioma.

Palavras-chave: MODIS, Cerrado brasileiro, autocorrelação espacial 


\section{INTRODUCTION}

Habitat loss and fragmentation, and the consequent reduction of much of the Earth's biodiversity, have been caused by the increasing human population density and energy use, mainly after the XIX and XX centuries (Sala et al., 2000; Fahring, 2003). Understanding how habitats respond to human impacts at broader geographical scales is a major research challenge, but most studies are still performed at local scales or focusing on specific habitats (but see Balmford et al., 2001).

The Cerrado biome, the second largest biome in Neotropical region, consists of a mosaic of different habitat types, ranging from open grasslands to dense woodlands and dry forests (Ribeiro \& Walter, 1998; see Furley, 2007 for a review). The Cerrado is the richest savanna ecosystem in the world, but the intensive human occupation process has also transformed it into one of the most important regions for cattle ranching and commodity crops in Brazil. Because of these two characteristics, the Cerrado was classified as one of the world's biodiversity hotspots (Myers et al., 2000). The proportion of remaining habitats in the Cerrado to vary from $39 \%$ to $55 \%$ (e.g., Mantovani \& Pereira, 1998; Eva et al., 2004; Machado et al., 2004; Sano et al., 2008). Recent (unpublished) data, generated by the Cerrado Warning Deforestation System (SIAD) (Ferreira et al., 2007a), indicate about $18,980 \mathrm{~km}^{2}$ of new deforestation between 2003 and 2007 (see www.ufg.br/lapig). Regardless of whether one accepts pessimistic or optimistic estimates of habitat loss, which depend on methodological issues such as geographic limits and mapping scale, it is certain that true conversion rates are high, have been increasing in time and are spreading throughout the biome (Klink \& Machado, 2005; Ferreira et al., 2007b).

As these rapid human occupation processes are very recent and complex, the losses are certainly strongly structured in space and time. Here we used a macroecological approach (see Kent, 2005; Gaston, 2006) to evaluate broad-scale spatial patterns of agriculture, habitat loss and climatic in the Brazilian Cerrado, discussing a general model that may give policy makers relevant scientific information for conservation planning at biome scale.

\section{MATERIALAND METHODS}

\section{Data}

Data on habitat loss were derived from the Cerrado Remnant Vegetation Map, recently released within the scope of the Brazilian Ministry of the Environment Biodiversity Program (Brazilian Ministry of Environ- ment - MMA), Conservation and Sustainable Use of Brazilian Biodiversity Project - PROBIO), which is freely available at $<$ http://mapas.mma.gov.br/mapas/ aplic/probio/datadownload.htm?/>. This map, comprising both a wide range of remnant physiognomies and converted areas, was produced at the 1:250,000 scale. It is relied on unsupervised classification (image segmentation) and visual interpretation of 114 Landsat scenes from 2002 (mostly from August, September, and October), analysis of MODIS vegetation index temporal datasets, ancillary landscape information from the former RadamBrasil project, and ground truth (see Sano et al., 2007 for details). As continued validation initiatives have demonstrated, this map represents the most detailed knowledge of the biome's remaining vegetation and human induced changes currently available. For this particular study, only the remnant physiognomies, grouped into a single remnant class, were considered. Specifically, the vector limits of each remnant vegetation patch were intercepted with a $1^{\circ}$ resolution vector grid, so that a \% value was added to the respective grid cell covering the Cerrado biome. This Cerrado grid system used here is composed by 181 cells with $1^{\circ} \mathrm{u} 1^{\circ}$ of latitude and longitude (Figure 1A) and was previously defined for biodiversity analyses (see Diniz-Filho et al. 2005, 2006; Bini et al., 2006; Pinto et al. 2007; Blamires et al., 2008). Grid cell size was chosen as a compromise between omission and commission errors when dealing with geographic distributions of species (see Luck, 2007; Heikkinen et al., 2006).

Data on social and economic variables that are likely to indicate human occupation were compiled from the Brazilian Institute of Geography and Statistics (IBGE) (see www.ibge.gov.br) and Institute of Applied Economic Research (IPEA) (see www.ipea.gov.br). In all, 23 variables were selected to express both the general patterns of human occupation (population size, growth rates, spatial subdivisions of the agricultural space and size of the road network) and the regional variations in agricultural and agro-industrial characteristics, which mainly reflect a contrast between more traditional and more capital-intensive agricultural practices (see Table 1 and Rangel et al., 2007 for a detailed description on the variables used).

As there is also evidence that agricultural patterns and human occupation are at least in part driven by environmental suitability and climatic conditions (e.g. Laurance et al., 2002), habitat remnants were also modelled as a function of climatic variables usually applied to predict biodiversity patterns at broad spatial scales (e.g. Rodríguez et al., 2005). We used five environmental variables related to ambient energy, mea- 


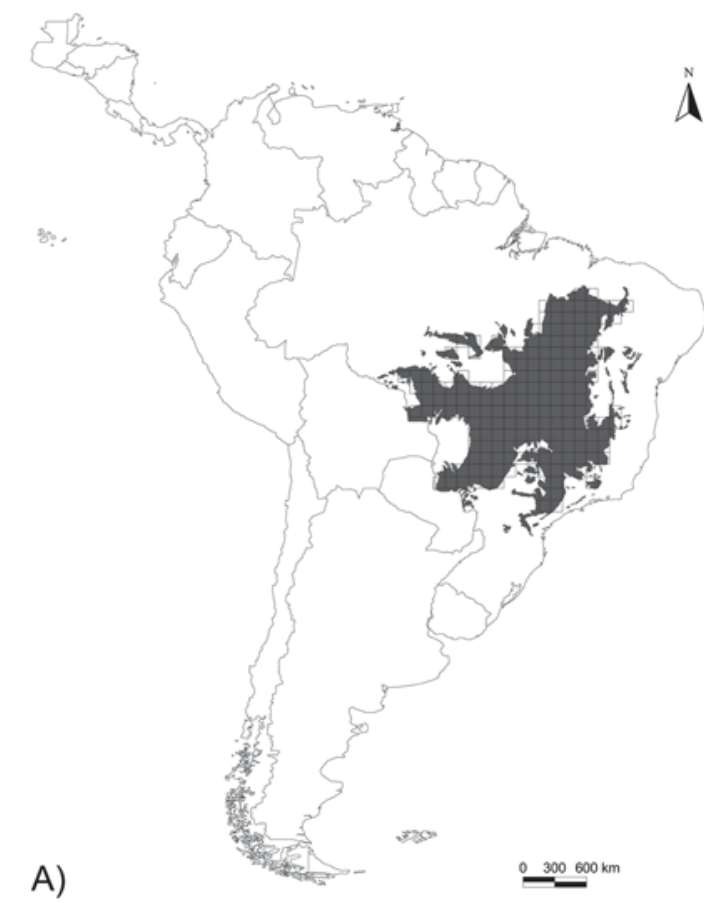

A

Figure 1 - The Cerrado region in Central Brasil (A) and the Gabriel's network linking the centroids of the 181 cells of $1^{\circ}$ of latitude and longitude covering the biome (B).

Table 1 - Codes and meaning of socio-economic variables used in this study and resulted from Rangel et al. (2007).

\begin{tabular}{|c|c|}
\hline Variable/code & Description \\
\hline Rural pop. & Percentage of rural population \\
\hline Workers & Number of workers employed at rural establishments \\
\hline Forests & Percentage of rural areas conserved as natural or recovered forests \\
\hline Pastures & Percentage of rural areas used as planted pastures \\
\hline Crops & Percentage of rural areas used as crops \\
\hline Area 100 & Percentage of rural establishments with area $\mathrm{p} 100$ ha \\
\hline Rice & Land productivity of rice in tons \\
\hline Corn & Land productivity of corn in tons \\
\hline Soy & Land productivity of soybean in tons \\
\hline Irrigation & Percentage of irrigated establishments \\
\hline Bovines & Cattle/ha \\
\hline AnimSum & Total monetary value of animal production \\
\hline VegeSum & Total monetary value of vegetal production \\
\hline Costs & Percentage of costs involved agriculture and cattle ranching \\
\hline Machines & $\begin{array}{l}\text { Density of farming machines (trucks, harvesting machines, tractors and automobiles) per unit of } \\
\text { area (ha) }\end{array}$ \\
\hline Plague/weed control & Percentage of rural establishments that use any resources against plagues or weeds \\
\hline Fertilization & Percentage of rural establishments that use any sort of fertilizers \\
\hline Electric energy & Percentage of rural establishments that use electric power \\
\hline Erosion control & Percentage of rural establishments that use any measure against erosion \\
\hline Fecundity & Expected number of children per woman \\
\hline Roads & Road network size $(\mathrm{km})$ \\
\hline Income & Income per capita \\
\hline H2000 & Human population in 2000 year \\
\hline
\end{tabular}


sured by Potential EvapoTranspiration (PET) and mean monthly annual temperature (TEMP), to water-energy balance. They are expressed by annual Actual EvapoTranspiration (AET) and by mean monthly annual precipitation (PREC) and to ambient productivity, expressed by the MODIS Enhanced Vegetation Index (EVI) (Huete et al., 2002). The EVI, a reliable surrogate for plant canopy density and greenness, total standing biomass, green leaf-area index, and percent vegetation cover (Ferreira et al., 2003; Ratana et al., 2005), was obtained as monthly averaged composites for the years 2004-2005.

\section{Data Analysis}

As a first approach, we used a standard multiple regression (OLS) (Sokal \& Rohlf, 1995) to model the influence of human occupation and climate on the percentage of natural remnants in each of the 181 cells, focusing on the amount of variations in habitat remnants that could be explained by these factors. Secondly, spatial patterns in response and predictor variables, as well as in model residuals, were assessed via Moran's I coefficients (Legendre \& Legendre, 1998; Diniz-Filho et al., 2003). The spatial relationship among cells covering the Cerrado was based on a Gabriel's network (Figure 1b) (see Legendre \& Legendre, 1998; Vieira et al., 2008). In Gabriel network, two cells are connected by an edge (are "linked") if the circle whose diameter links the two cell centroids does not include any other centroid. Linked centroids are then assigned as 1.0 in connectivity matrix $(\mathbf{W})$, which is the core of Moran's I autocorrelation index, given as

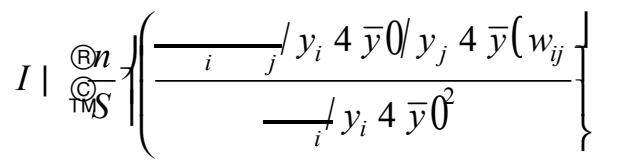

where $n$ is the number of samples (local populations), $\mathrm{y}_{i}$ and $\mathrm{y}_{j}$ are the values of the allele frequencies (or any quantitative trait) measured in the populations, $i$ and $j$, $\bar{y}$ is the average of $y$ and $w_{i j}$ is an element of the matrix $\mathbf{W}$. In $\mathbf{W}$, the elements are equal to 1 if the pair $i, j$ of local populations is within a given distance class interval (indicating populations that are "connected" in this class), and $w_{\mathrm{ij}}=0$ otherwise. $S$ indicates the number of entries (connections) in the $\mathbf{W}$ matrix. The value expected under the null hypothesis of the absence of spatial autocorrelation is $-1 /(n-1)$.

Because significant spatial autocorrelation was detected in the OLS residuals using Moran's I autocorrelation coefficient, statistical tests are not strictly valid and this may create difficulties when interpreting the effects of predictors on habitat remnants (see Legendre \& Legendre, 1998; Diniz-Filho et al.,
2003). Moreover, it indicates that there are spatial components underlying variation in habitat remnants that are not taken into account by environmental predictors and human occupation, so that spatial regression methods could be used to assess these components. Here, an eigenvector-based spatial filtering approach (see Griffith 2003; Diniz-Filho \& Bini, 2005; Griffith \& Peres-Neto, 2006; Dormann et al., 2007), called Spatial Eigenvector Mapping (SEVM) was applied to model the spatial patterns in the amount of habitat remnants. The idea of SEVM is to use the eigenvectors associated with the positive eigenvalues of the doublecentered $\mathbf{W}$ connectivity matrix to express the relationship among cells covering the Cerrado at multiple spatial scales. The first eigenvectors represent broadscale variation, whereas eigenvectors derived from small eigenvalues represent fine-scale variation. These vectors are then orthogonal variables that capture, at different scales, the geometry of the grid covering the Cerrado and thus can be incorporated into multiple regression models in different ways. All spatial analyses were performed in Spatial Analysis in Macroecology (SAM) software (Rangel et al., 2006), freely available at $<$ www.ecoevol.ufg.br/sam $>$.

Another important issue is that all these datasets (matrices of socio-economic variables $\mathbf{H}$, climate conditions $\mathbf{C}$ and spatial structure defined by eigenanalysis, G) are probably strongly interconnected, so that a partial regression approach was also used to partition the spatial variation in the amount of habitat remnants per cell into multiple components, as explained in detail in Lobo et al. (2002). Table 2 summarizes the steps involved in the estimation of shared effects of explanatory variables (spatial + climatic, spatial + human occupation and human occupation + climatic), as well the effects attributed purely to space, climate and human occupation.

\section{RESULTS}

On average, $59 \%$ of the area in each cell $( \pm 27 \%$, standard deviation) is occupied by natural remnants. However, patterns of habitat loss are strongly spatially structured across the biome throughout the Gabriel connection between cell centroids, with a Moran's $I$ coefficient equal to $0.825 \pm 0.055(p<0.001)$. There is a very large variation in the percentage of remnants, ranging from an almost complete loss of natural vegetation in some cells in the southern part of the biome, up to almost $100 \%$ of natural cover in the north (Figure 2).

The 23 socio-economic variables explained together $83 \%$ of the total variation on percentage of remnants; whereas the 5 climatic variables explain $65.5 \%$ of the 
Table 2 - Detailed explanation of the calculations of partial components, based on Lobo et al. (2002), for three sets of predictors. The three components analyzed here are 23 socio-economic variables expressing human occupation (H), 5 climatic variables $(\mathbf{C})$ and 15 eigenvectors extracted from geographical connectivity matrix $\mathbf{W}$ among cells, expressing then spatial structure in our grid system $(\mathbf{G})$. These three sets of predictors were used to explain variation in percentage of natural remnants (Y) in Brazilian Cerrado. At each step, the response variable is regressed against a group of predictors, so that the $\mathrm{R}^{2}$ can be interpreted as fractions of total variance shown in Figure 1. Some of the steps involve regressing all variables in one set of predictor against the other set and getting the model residuals that will be used in a next step.

\begin{tabular}{|c|c|c|c|c|c|}
\hline Step & Response & Predictors & Fractions & Residual & Intepretation of $R^{2}$ \\
\hline 1 & $Y$ & $\mathbf{G}, \mathbf{H}, \mathbf{C}$ & $a+b+c+d+e+f+g$ & & total variance explained \\
\hline 2 & $Y$ & $\mathbf{G}$ & $a+d+e+g$ & & explained by geography \\
\hline 3 & $Y$ & $\mathbf{H}$ & $b+d+f+g$ & & explained by human occupation \\
\hline 4 & $Y$ & $\mathbf{C}$ & $c+e+f+g$ & & explained by climatic variation \\
\hline 5 & $Y$ & G, $\mathbf{H}$ & & & \\
\hline 6 & $Y$ & G, $\mathbf{C}$ & & & \\
\hline 7 & $Y$ & $\mathrm{H}, \mathrm{C}$ & & & \\
\hline 8 & G & $\mathbf{H}, \mathbf{C}$ & & $\mathbf{G}_{(\mathrm{H}, \mathrm{C})}$ & \\
\hline 9 & $Y$ & $\mathbf{G}_{(\mathbf{H}, \mathbf{C})}$ & $a$ & & purely explained by $\mathbf{G}$ \\
\hline 10 & $\mathbf{C}$ & $\mathbf{G}, \mathbf{H}$ & & $\mathbf{C}_{(\mathrm{G}, \mathrm{H})}$ & \\
\hline 11 & $Y$ & $\mathbf{C}_{(\mathbf{G}, \mathbf{H})}$ & $b$ & & purely explained by $\mathbf{C}$ \\
\hline 12 & $\mathbf{H}$ & G, $\mathbf{C}$ & & $\mathbf{H}_{(\mathrm{G}, \mathrm{C})}$ & \\
\hline 13 & $Y$ & $\mathbf{H}_{(\mathbf{G}, \mathbf{C})}$ & $c$ & & purely explained by $\mathbf{H}$ \\
\hline 14 & & & $d+e+g=\left(R_{\text {Step } 2}^{2}\right)-\left(R_{\text {Step } 9}^{2}\right)$ & & \\
\hline 15 & & & $d+f+g=\left(R_{\text {Step } 3}^{2}\right)-\left(R_{\text {Step } 13}^{2}\right)$ & & \\
\hline 16 & & & $e+f+g=\left(R_{\text {Step } 4}^{2}\right)-\left(R_{\text {Step } 11}^{2}\right)$ & & \\
\hline 17 & & & $d=\left(R_{\text {Step } 5}^{2}\right)-\left(R_{\text {Step 16 }}^{2}\right)-\left[\left(R_{\text {Step } 9}^{2}\right)+\left(R_{\text {Step 13 }}^{2}\right)\right]$ & & variation shared by $\mathbf{G}$ and $\mathbf{H}$ \\
\hline 18 & & & $e=\left(R_{\text {Step } 6}^{2}\right)-\left(R_{\text {Step 15 }}^{2}\right)-\left[\left(R_{\text {Step } 9}^{2}\right)+\left(R_{\text {Step 11 }}^{2}\right)\right]$ & & variation shared by $\mathbf{G}$ and $\mathbf{C}$ \\
\hline 19 & & & $f=\left(R_{\text {Step } 7}^{2}\right)-\left(R_{\text {Step 14 }}^{2}\right)-\left[\left(R_{\text {Step 11 }}^{2}\right)+\left(R_{\text {Step 13 }}^{2}\right)\right]$ & & variation shared by $\mathbf{H}$ and $\mathbf{C}$ \\
\hline 20 & & & $g=\left(R_{\text {Step 14 }}^{2}\right)-\left(R_{\text {Step 17 }}^{2}\right)-\left(R_{\text {Step 18 }}^{2}\right)$ & & variation shared by $\mathbf{G}, \mathbf{H}$ and $\mathbf{C}$ \\
\hline
\end{tabular}

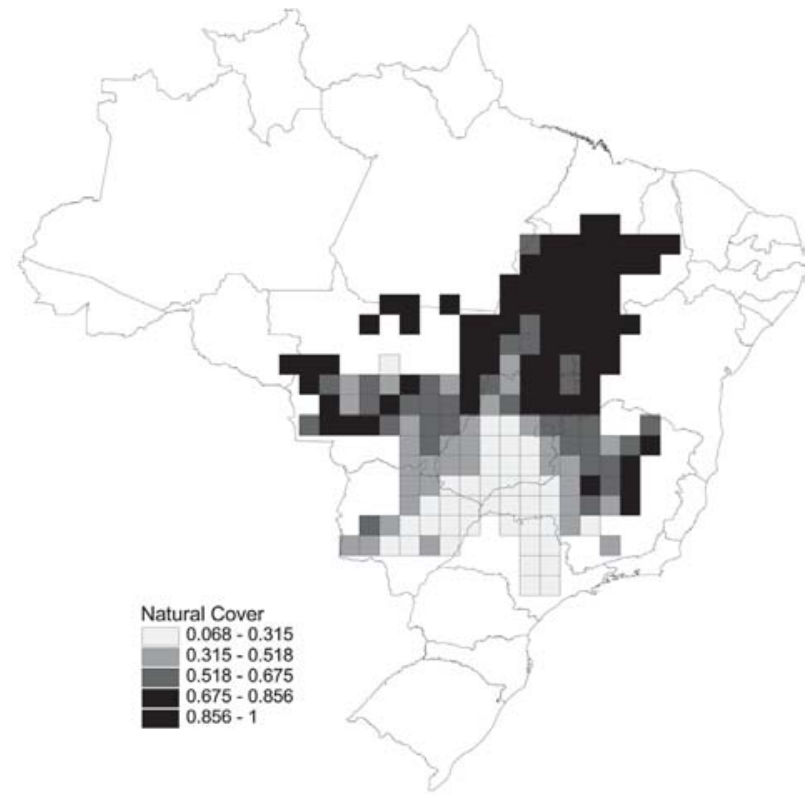

Figure 2 - Spatial patterns of proportion of natural remnants in Brazilian Cerrado. spatial pattern (the two groups of variables together explain $84.2 \%$ of the variation). However, in both models there were significant spatial autocorrelation in the residuals $(I=0.233 \pm 0.054$ for socio-economic model residuals, $I=0.436 \pm 0.053$ for climatic model residuals, and $I=0.233 \pm 0.056$ for both sets of predictors combined). Thus, spatial structures must be explicitly taken into account in the model.

This was accomplished through a set of 87 eigenvectors with positive eigenvalues, extracted from the double-centred $\mathbf{W}$ connectivity matrix based on Gabriel's network among cells. Out of these, 74 showed Moran's $I$ larger then 0.1 , and then we successively added these eigenvectors until the $R^{2}$ of the multiple regression started to stabilize and the suppression of autocorrelation in the OLS model residuals ( $I$ $=0.06 ; p>0.05)$. Thus, the first 15 spatial eigenvectors were retained for further analysis (as the matrix G), although only eigenvectors one and four were statistically significantly correlated to the remnants' percentage. 
After incorporating the 15 eigenvectors, the full model (incorporating socio-economic, climatic variables and spatial eigenvectors) explained $89 \%$ of the variation in percentage of the remnants across the biome, and no significant residual autocorrelation remained $(I=0.033 \pm 0.054 ; p>0.05)$. Highest partial regression coefficients in the full multiple regression model were found for corn production, percentage of the rural establishments using electric energy, total animal production and herd size (see Rangel et al., 2007, for details). However, because of the complexity of overlap among socio-economic, climatic and geographical effects (see below), it is difficult to establish the individual contribution of each variable within each set. Anyway, this suggests that habitat losses were mainly related to, first, cattle ranching, and second, agricultural activities. In terms of climatic variables, the only significant partial regression coefficient appears for monthly annual precipitation, so that areas with higher amount of habitat loss are the driest ones, after taking all other variables and spatial patterns into account.

The partial regression analysis (Figure 3 ) revealed that $7 \%$ of the variation in habitat loss along the Cerrado biome can be explained by non-spatial, localized effects of human occupation, after taking into account climatic variation. Unique geographical (i.e., geographic factors independent of climatic and human occupation variables measured here) and climatic patterns alone explain $5 \%$ and $2 \%$ of the variation in per-

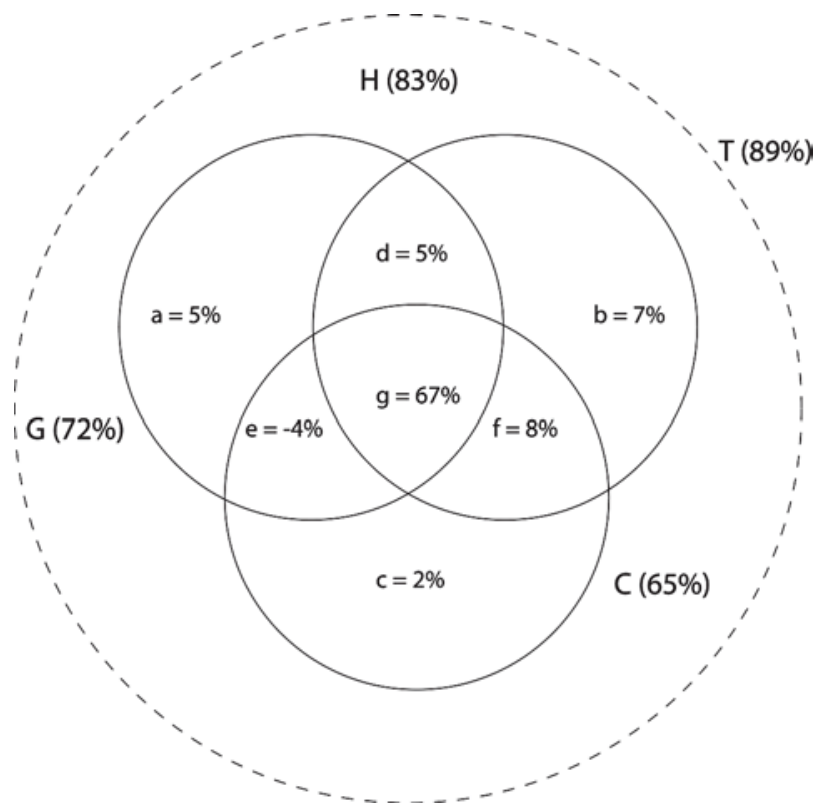

Figure 3 - Visual representation of results from partial regression analysis explaining the proportion of natural remnants, showing the amount of total variation explained by socio-economic, climatic and spatial variables and their multiple overlaps. centage of remnants, respectively. Actually, the highest proportion of variance in the response is explained by the multiple overlap between $\mathbf{G}, \mathbf{H}$ and $\mathbf{C}(67 \%)$, as well as by the climatically structured component of human occupation (8\%). Both climatic and human occupation components, then, have a strong geographical trend that explains most of the variation in the percentage of habitat remnants.

\section{DISCUSSION}

At broad spatial scales, the percentage of natural remnants in the Brazilian Cerrado is strongly spatially structured, with a north-south and east-west gradient of decreasing values. About $59 \%$ of the area in each cell is occupied by natural remnants, indicating an average rate of habitat loss around $40 \%$, closer to the more optimistic recent estimates. However, differences between these estimates and previous ones (e.g., Myers et al., 2000; Jepson, 2005; Klink \& Machado, 2005) may be due to several issues, especially related to spatial scales used here and problems in using moderate resolution imagery to define natural vegetation and assess human impacts.

Perhaps more important than the average values observed and widely discussed in the literature, the most striking point revealed here is that there is an enormous spatial variation around these averages, ranging from an almost complete loss of natural vegetation, mainly in some cells in the southern part of the biome (e.g. Durigan et al., 2007), up to almost 100\% (at our grid resolution) of natural cover in the northern areas. Although the amount of habitat loss may be dependent of data sources and techniques, it is unlikely that they provide very different maps at the broad-scale resolution used in the analyses performed here. So, our main conclusions would be qualitatively unaffected by these estimates of habitat loss and fragmentation at local scales. Moreover, although the classification of the Cerrado as a biodiversity hotspot was due to high levels of habitat loss and number of endemic plant species, the link between the current conservation status and threat levels may be more complex than revealed by a single time slice analysis, because temporal trends almost surely underlay the observed correlations. By considering our knowledge on the human occupation of the Cerrado region in the last 50 years (see Klink \& Moreira,, 2002; Klink \& Machado, 2005; Bini et al., 2006), it is possible to link spatial and historical patterns to understand the relationships observed here to explain the patterns of habitat loss.

There is a clear relationship between the spatial pattern in frequency of natural remnants and current patterns of human occupation in the Cerrado, which in 
turn is also a strongly spatially (and temporally) structured process. The full model explains almost $90 \%$ of the variation in the Cerrado remnants, whereas local, non-geographically structured human occupation and climatic components independent of human occupation explain small parts of the total variation. As commonly observed in studies at broad spatial scales, most of the variation cannot be entirely disentangled among the components analysed, and the unique (not shared) contribution of each set of predictors independently of the others is usually very low. Indeed, the most important component explaining spatial variation in the percentage of natural remnants is exactly the shared variation among all sets of predictors analyzed (67\%), revealing the strong spatial component in both human occupation and climatic variation affecting the amount of habitat remnants. There is also a slightly larger proportion of variation attributed to the association between climatic variation and socio-economic variables, independent of all other factors, and between spatial eigenvectors and socio-economic variables (i.e., expressing them the spatially-structured component of human occupation).

These correlations make sense by considering the spatio-temporal dynamics of the recent process of human occupation of the Brazilian Cerrado, which was characterized by successive wave fronts of colonization coming from the south and southeastern parts of the country since the 18th century (Klink \& Machado, 2005). There was a clear acceleration of this process after the transference of the national capital from Rio de Janeiro to Brasília, in 1960. Besides, many governmental programs were created to attract modern and highly technological agriculture (see Klink \& Moreira, 2002; Cavalcanti \& Joly, 2002; Klink \& Machado, 2005; Brannstrom et al., 2008). On the other hand, fewer populated regions in the northern Cerrado are still under a process of human occupation and scientific-technological development.

Partial regressions also reveal relative large amounts of explanation in the shared components between climate and human occupation (8\%), and in the spatiallystructured human occupation (around 5\%). The amount of overlap between climate and human occupation (independently of geographic space) may indicate at least minor technological restrictions during the agricultural expansion, in part supporting claims that agriculture is better developed in favorable climatic regions, especially in the absence of modern and expensive technology (see Balmford et al., 2001). Also, future climate changes are expected to affect agricultural patterns. In this case, the complex relationships here observed suggest that geographically-structured agricultural expansion towards the northern part of the biome, also favored by climatic shifts in this direction, will promote even higher rates of habitat losses in the northern part of the biome. These synergetic effects are currently supported by the high amounts of variance explained in the partial regression by the shared components among the sets of predictors evaluated here.

Based on the relationship between current human occupation and percentage of natural remnants, future scenarios should be rather pessimistic (Scarano, 2007). If the wave of human occupation continues towards the northern parts of the biome, as expected, we can predict those percentages will decline fast, inducing even stronger habitat losses (and eventually of biodiversity) at the biome scale.

\section{ACKNOWLEDGEMENTS}

We thank two anonymous reviewers for suggestions that improved previous versions of the paper. Financial support for this study came from a PRONEX program of CNPq and SECTEC-GO (proc. 23234156). Work by J.A.F.D.-F., L.M.B. and L.G.F. were also partially supported by other $\mathrm{CNPq}$ productivity fellowships, whereas G.O. is supported by CAPES graduate fellowships. Our research program in macro ecology and biodiversity has also been continuously supported by CAPES and FUNAPE-UFG.

\section{REFERENCES}

BALMFORD, A.; MOORE, J.L.; BROOKS, T.; BURGESS, N.; HANSEN, L.A.; WILLIAMS, P.; RAHBEK, C. Conservation conflicts across Africa. Science, v.291, p.2616-2619, 2001.

BINI, L.M.; DINIZ-FILHO, J.A.F.; RANGEL, T.F.L.V.B.; BASTOS, R.P.; PINTO, M.P. Challenging Wallacean and Linnean shortfalls: knowledge gradients and conservation planning in a biodiversity hotspot. Diversity and Distributions, v.12, p.475-482, 2006.

BLAMIRES, D.; OLIVEIRA, G.; BARRETO, B.S.; DINIZ-FILHO, J.A.F. Habitat use and deconstruction of richness patterns in cerrado birds Acta Oecologica, v.33, p.97-104, 2008.

BRANNSTROM, C.; JEPSON, W.; FILIPPI A.M.; REDO, D.; XU, Z.; GANESH, S. Land change in the Brazilian Savanna (Cerrado), 1986-2002: Comparative analysis and implications for landuse policy. Land Use Policy, v.25, p.579-595, 2008.

CAVALCANTI, R.B.; JOLY, C.A. Biodiversity and conservation priorities in the Cerrado. In: OLIVEIRA, M.S.; MARQUIS, R.J. (Ed.) The Cerrados of Brazil: ecology and natural history of Neotropical savanna. New York: Columbia University Press, 2002. cap.18, p.351-367.

DINIZ-FILHO, J.A.F.; BINI, L.M.; HAWKINS, B.A. Spatial autocorrelation and red herrings in geographical ecology. Global Ecology and Biogeography, v.12, p.53-64, 2003.

DINIZ-FILHO, J.A.F.; BASTOS, R.P.; RANGEL, T.F.L.V.B.; BINI, L.M.; CARVALHO, P.; SILVA, R.J. Macroecological correlates and spatial patterns of anuran description dates in the Brazilian Cerrado. Global Ecology and Biogeography, v.14, p.469477, 2005.

DINIZ-FILHO, J.A.F.; BINI, L.M. Modelling geographical patterns in species richness using eigenvector-based spatial filters. Global Ecology and Biogeography, v.14, p.177-185, 2005. 
DINIZ-FILHO, J.A.F.; BINI, L.M.; PINTO, M.P.; RANGEL, T.F.L.V.B.; CARVALHO, P.; BASTOS, R.P. Anuran species richness, complementarity and conservation conflicts in Brazilian Cerrado. Acta Oecologica, v.29, p.9-15, 2006.

DORMANN, C.F.; MCPHERSON, J.; ARAÚJO, M.B.; BIVAND, R.; BOLLIGER, J.; CARL, G.; DAVIES, R.G.; HIRZEL, A.; JETZ, W.; KISSLING, W.D.; KÜHN, I.; OHLEMÜLLER, R.; PERESNETO, P.; REINEKING, B.; SCHRÖDER, B.; SCHURR, F.M.; WILSON, R. Methods to account for spatial autocorrelation in the analysis of distributional species data: a review. Ecography, v.30, p.609-628, 2007.

DURIGAN, G.; DE SIQUEIRA, M.F.; FRANCO, G.A.D.C. Threats to the Cerrado remnants of the State of São Paulo, Brazil. Scientia Agricola, v.64, p.355-363, 2007

EVA, H.D.; BELWARD, A.S.; DE MIRANDA, E.E.; DI BELLA, C.M.; GOND, V.; HUBER, O.; JONES, S.; SGRNZAROLI, M.; FRITZ, S. A land cover map of South America. Global Change Biology, v.10, p.731-744, 2004.

FAHRING, L. Effects of habitat fragmentation on biodiversity. Annual Review of Ecology, Evolution and Systematics, v.34, p.487-515, 2003.

FERREIRA, L.G.; YOSHIOKA, H.; HUETE, A.; SANO, E.E. Seasonal landscape and spectral vegetation index dynamics in the Brazilian Cerrado: an analysis within the Large-Scale Biosphere-Atmosphere Experiment in Amazonia (LBA). Remote Sensing of Environment, v.87, p.534-550, 2003.

FERREIRA, N.C.; FERREIRA, L.G.; HUETE, A.R.; FERREIRA, M.E. An operational deforestation mapping system using MODIS data and spatial context analysis. International Journal of Remote Sensing, v. 28, p.47-62, 2007a.

FERREIRA, M.E.; FERREIRA, L.G.; FERREIRA, N.C.; ROCHA, G.F.; NEMAYER, M. Desmatamentos no bioma Cerrado: uma análise temporal (2001-2005) com base nos dados MODIS MOD13Q1. In: SIMPÓSIO BRASILEIRO DE SENSORIAMENTO REMOTO, 13, Florianópolis, 2007b, Anais. São José dos Campos: INPE, 2007. v.1, p.3877-3883.

FURLEY, P.A. Tropical savannas and associated forests: vegetation and plant ecology. Progress in Physical Geography, v.31, p.203-211, 2007

GASTON, K.J. Biodiversity and extinction: macroecological patterns and people. Progress in Physical Geography, v.30, p.258-269, 2006.

GRIFFITH, D.A. Spatial autocorrelation and spatial filtering: gaining understanding through theory and scientific visualization. New York: Springer, 2003. 223p.

GRIFFITH, D.A.; PERES-NETO, P.R. Spatial modeling in ecology: the flexibility of eigenfunction spatial. Ecology, v.87, p.26032613,2006

HEIKKINEN, R.K.; LUOTO, M.; ARAÚJO, M.B.; VIRKKALA, R.; THUILLER, W.; SYKES, M.T. Methods and uncertainties in bioclimatic envelope modeling under climate change. Progress in Physical Geography, v. 30 , p.751-777, 2006

HUETE, A.; DIDAN, K.; MIURA, T.; RODRÍGUEZ, E.P.; GAO, X.; FERREIRA, L.G. Overview of the radiometric and biophysical performance of the MODIS vegetation indices. Remote Sensing of Environment, v.83, p.195213, 2002

KENT, M. Biogeography and macroecology. Progress in Physical Geography, v.29, p.256-264, 2005.

KLINK, C.A.; MOREIRA, A.G. Past and current human occupation, and land use. In: OLIVEIRA, M.S.; MARQUIS, R.J. (Ed.) The Cerrados of Brazil: ecology and natural history of Neotropical savanna. New York: Columbia University Press, 2002. cap.5, p.69-90.

KLINK, C.A.; MACHADO, R.B. Conservation of the Brazilian Cerrado. Conservation Biology, v.19, p.707-713, 2005.

JEPSON, W. A disappearing biome? Reconsidering land-cover change in the Brazilian savanna. The Geographical Journal, v.171, p. $99-111,2005$.
LAURANCE, W.F.; ALBERNAZ, A.K.M.; SCHROTH, G.; FEARNSIDE, P.M.; BERGEN, S.; VENTICINQUE, E.M.; DA COSTA, C. Predictors of deforestation in the Brazilian Amazon. Journal of Biogeography, v.29, p.737-748, 2002.

LEGENDRE, P.; LEGENDRE, L. Numerical ecology. Amsterdam: Elsevier, 1998. 853p.

LOBO, J.M.; LUMARET, J.; JAY-ROBERT, P. Modelling the species richness distribution of French dung beetles (Coleoptera, Scarabaeidae) and delimiting the predictive capacity of different groups of explanatory variables. Global Ecology and Biogeography, v.11, p.265-277, 2002.

LUCK, G.W. The relationships between net primary productivity, human population density and species conservation. Journal of Biogeography, v.34, p.201-212, 2007.

MACHADO, R.B.; RAMOS NETO, M.B.; PEREIRA, P.G.P.; CALDAS, E.F.; GONCALVES, D.A.; SANTOS, N.S.; TABOR, K.; STEININGER, M. Estimativas de perda da área do Cerrado Brasileiro. Conservation International, [technical report], 2004.

MANTOVANI, J.E.; PEREIRA, A. Estimating the integrity of the Cerrado vegetation cover through the Landsat-TM data. In: SIMPÓSIO BRASILEIRO DE SENSORIAMENTO REMOTO, 9, Santos, 1998. Proceedings. São José dos Campos: Brazilian Institute for Space Research, INPE), 1998. CD-ROM.

MYERS, N.; MITTERMEIER, R.A.; MITTERMEIER, C.G.; FONSECA, G.A.B.; KENTS, J. Biodiversity hotspots for conservation priorities. Nature, v.403, p.853-858, 2000.

PINTO, M.P.; MATHIAS, P.V.C.; BLAMIRES, D.; DINIZ-FILHO, J.A.F.; BINI, L.M. Selecting priority areas to conserve Psittacines in the Brazilian Cerrado: minimizing human-conservation conflicts. Bird Conservation International, v.17, p.13-22, 2007.

RANGEL, T.F.L.V.B.; DINIZ-FILHO, J.A.F.; BINI, L.M. Towards an integrated computational tool for spatial analysis in macroecology and biogeography. Global Ecology and Biogeography, v.15, p.321-327, 2006.

RANGEL, T.L.F.V.B.; BINI, L.M.; DINIZ - FILHO, J.A.F.; PINTO, M.P.; CARVALHO, P.; BASTOS, R.P. Human development and biodiversity conservation in Brazilian Cerrado. Applied Geography, v.27, p.14-27, 2007.

RATANA, P.; HUETE, A.; FERREIRA, L.G. Analysis of Cerrado physiognomies and conversion in the MODIS seasonal-temporal domain. Earth Interactions, v.9, p.1-22, 2005.

RIBEIRO, J.F.; WALTER, B.M.T. Fitofisionomias do bioma Cerrado. In: SANO, S.M.; ALMEIDA, S.P. (Ed.) Cerrado: ambiente e flora. Planaltina: Embrapa-CPAC, 1998. p.89-166

RODRÍGUEZ, M.A.; BELMONTES, J.A.; HAWKINS, B.A. Energy, water and large-scale patterns of reptile and amphibian species richness in Europe. Acta Oecologica, v.28, p.65-70, 2005.

SALA, O.E.; CHAPIN, F.S.3RD; ARMESTO, J.J.; BERLOW, E.; BLOOMFIELD, J.; DIRZO, R.; HUBER-SANWALD, E.; HUENNEKE, L.F.; JACKSON, R.B.; KINZIG, A.; LEEMANS, R.; LODGE, D.M.; MOONEY, H.A.; OESTERHELD, M.; POFF, N.L.; SYKES, M.T.; WALKER, B.H.; WALKER, M.; WALL, D.H. Global biodiversity scenarios for the year 2100. Science, v.287, p.1770-1774, 2000.

SANO, E.E.; ROSA, R.; BRITO, J.L.S.; FERREIRA, L.G. Mapeamento de cobertura vegetal do bioma Cerrado: estratégias e resultados. Planaltina: Embrapa Cerrados (Boletim de Pesquisa), 2007.

SANO, E.E.; ROSA, R.; BRITO, J.L.S.; FERREIRA, L.G. Mapeamento semidetalhado do uso da terra do Bioma Cerrado. Pesquisa Agropecuária Brasileira, v.43, p.153-156, 2008.

SCARANO, F.R. Perspectives on biodiversity science in Brazil. 2007. Scientia Agricola, v.64, p.439-447, 2007

SOKAL, R.R.; ROHLF, F.J. Biometry. New York : W.H. Freeman, 1995. $887 \mathrm{p}$

VIEIRA, C.M.; BLAMIRES, D.; DINIZ-FILHO, J.A.F.; BINI, L.M.; RANGEL, T.F.L.V.B. Autoregressive modelling of species richness in Brazilian Cerrado. Brazilian Journal of Biology, v. $68,233-240,2008$

Received April 23, 2008

Accepted May 15, 2009 